\title{
太陽光利用にもっと付加価値を
}

\author{
中塚正大 \\ レーザー技術総合研究所（†565-0871 大阪府吹田市山田丘2-6）
}

\section{Solar Light Application with More Added-Values}

\author{
Masahiro NAKATSUKA \\ Institute for Laser Technology, Yamada-oka 2-6, Suita, Osaka 565-0871
}

(Received November 9, 2009)

\begin{abstract}
Solar energy application will be an ultimate path of energy development for the life of human being. Generally, useful aims of such application have been lower efficiency in an ecological viewpoint. Higher added values to the application are expected to solar energy generation system. Solar-pumped lasers give us high-power coherent light as a lower entropy resource. A high-temperature chemistry under a strong focusability of laser light is challengeable research in future.
\end{abstract}

Key Words: Solar-pumped lasers, Nd/Cr:YAG laser, Energy transportation, High temperature chemistry, Efficient concentration of solar light.

\section{1.なぜ太陽光利用か?}

言うまでもなく，現在の地球環境の問題は大気温度の 歴史的な上昇から来ている。大気温度は流入する太陽工 ネルギーや地球内から発するエネルギー量と地球から輻 射で出るエネルギー量の差し引きで決まっている，地上 でのエネルギー利用量が過去に蓄積された化石エネル ギーの利用による量の増大と地球放出エネルギーが温暖 化ガスによる蓄積効果で減少していることが原問題であ る。エネルギー発生量に問題があるのではない，蓄積効 果に問題がある。従って, 回答は利用可能エネルギーの 発生において温室効果ガス放出を極力小さくすることで ある。

環境問題において太陽エネルギーの有効利用が言われ て久しい，地上に降り注ぐ太陽エネルギーの総量と比較 すると，人間活動に用いられている総エネルギー量は 微々たるものである。ただし，多くの太陽エネルギー利 用は分散的エネルギー源としての利用で，光エネルギー としての特徵を生かしたものではない，価值の高いエネ ルギー形態を追求することが重要である.

\section{2. 太陽光の利点と難点は?}

太陽光の地上でのエネルギー密度は $1 \mathrm{~kW} / \mathrm{m}^{2}$ 程度で大 きな数值ではない. 戸建住宅の南面設置屋根では $5 \mathrm{~kW}$ 程度の出力が可能で分散電源として利用されている。 日 照時間の定義は快晴時の10分の1以上の照度での計算で
年間1,500 2,000時間程度である。昼夜年間時間の約2割 に過ぎない。宇宙ではこの制約はない.

このことから分散型エネルギー源としての開発に併せ て，より付加価值の高いエネルギー形態への変換によっ て財産力の高い価值を生み出す視点が重要である.

太陽光による直接高温発生は太陽表面温度(約6,000 度)を超えることはない。実際には1,000～2,000度程度が 限界である。広帯域スペクトル光をレーザー化してコ ヒーレントな光に変換できると, 集光度の向上によって 連続光でも数千度以上，パルス光では数 10 万度の高温を 達成することが容易である.

またレーザー光化することで伝播ビーム拡散を極端に 小さくできるため, 伝播可能な距離を数万 $\mathrm{km}$ にまで拡 張できエネルギー伝送源とすることも可能である。静止 衛星軌道上に太陽励起レーザーを持ち上げ, 昼夜のない 環境から地上に1 GW級のエネルギーを伝送しようとい うS Space Solar Power System (SSPS) 計画が宇宙航空研究開 発機構 (JAXA)で検討されている.

$$
\text { 3. どのようなレーザーか? }
$$

なによりも太陽光の広帯域スペクトルの利用に対応で きるものでなくてはならない，固体レーザーは信頼性と 効率性において性能が高く, 産業用にも多用されてい

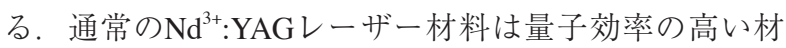
料として周知である。しかし, 励起吸収特性は結晶特有 の狭帯域吸収性で制限され，太陽光のように緑色に中心 
のある黒体輻射スペクトルを励起源とする場合には，実 現可能なレーザー効率に限界がある。

$\mathrm{Cr}^{3+}$ イオン $(400 \sim 600 \mathrm{~nm}$ 帯域に強い吸収)のコドープ によって太陽光の吸収効率は格段に上がり, $\mathrm{Nd}$ イオン へのエネルギー移袞過程も好都合にも効率的に動作す る. 青色や緑色スペクトル励起でのCrイオンの効果は絶 大で太陽光等の広帯域スペクトル励起におけるNd:YAG レーザーの機能増大が実現できる.

従来YAG結晶は単結晶として使われて来たが，ガー ネット結晶は等方性であるため多結晶からなるセラミッ クスもレーザー材料として動作可能であることが，10年 ほど前に神島化学やファインセラミックスセンターから 示された。 これは日本発の新技術であり, 現在でも世界 で商業化しているのはこの2組織のみである. 阪大レー ザー研でも基礎研究が進み, 特に粉体材料における種々 のドープ材料検討が進んでいる。この技術は大型化の問 題も特になく, 平板状では数 $10 \mathrm{~cm}$ 角の面積まで製作可 能となって来た。厚みについては製造技術上での制限が あるが焼結時の融着技術開発が進んでいる.

阪大でのYAG粉体での検討によると高濃度ドープ(吸 収中心のCrでは10\%ドープも可能)が実現でき, 極めて 薄い数mmの材料で太陽光を強く吸収することができ る。散乱問題の回避に有用である.

太陽光の効率的で低廉な集光システム設計はキーワー ドのひとつである. 現在, ランプ励起で基礎試験を行い つつ，機構設計を実施している，集光ミラー(福井大)は 大型化可能であるが, 将来は折り畳めるものなどの要請 があるので, プラスティックフィルム形式になるだろ う。フレネルレンズ (東工大) も集光系の候補のひとつで あるが集光効率は (色収差が大きく) 高くはない. 集光追 尾の必要性から, 最終的には超大型のフィルム雨金ミ ラーと2次集光ミラーになりそうである.

宇宙空間での利用においては, 装置冷却は放射冷却以 外にない．放射能率は物体の絶対温度の4乗で決まるの で, レーザー装置の高温動作の可能性を探ることは極め て重要である. Nd/Cr:YAGセラミックスレーザーは高温 での動作において効率向上の可能性があり, 現在詳細な 実験的研究が進められている。

\section{4. どのようなシステムか?}

太陽光は10 mrad程度の広がりをもつため集光に厳し い性能を求めることはできない。冷却の容易さからも平 板状のレーザー材料形態が適切で, 必然的にアクティブ ミラー形式の増幅器が最適である. 出力増大にはビーム 面積でかせぐ方式でスケーリングが容易である，出力 ビーム品質を高くするためには単一モード発振器と大型 増幅器の組み合わせが考えられる.

太陽光励起レーザーは励起源が不要なためシステム構 成も相当に簡単化される。ママリクス構成の多ユニット システムでも光結合の容易さから拡張性がある.

\section{5. 太陽レーザー光の応用は?}

太陽光をレーザー化することから応用先も付加価值の 高いものであることが望ましい，連続出力では遠距離伝 播の特徴を生かしたエネルギー源としてSSPS計画や月 面ローバー計画等が有る。地上では狭帯域で高効率の太 陽電池を組み合わせた太陽光発電計画がありえる。

パルス出力では高温発生応用が期待される. 地上で 2,000度を超える反応炉は困難であるが，レーザー加熱 では局所集光によって容器の問題が軽減される，還元反 応炉によって希少金属や付加価值の高い物質生産に適し ている。

\section{6. 本特集では}

今回，東工大，阪大，福井大，光大，レーザー総研な どから多種類の太陽励起レーザー開発と応用研究の現状 が報告される。セラミックス開発の材料研究から高温動 作試験, レーザー形態もアクティブミラー, ロッド型, ジグザグスラブと研究が棲み分けられている。応用先も エネルギー開発, 高出力伝送, 物質創製等たいへん興味 深く，今後に期待したい. 